\title{
Immunocompetence in relation to a heat-processed diet (Maillard reaction) in weanling rats
}

\author{
BY PILAR VARELA, MARÍA DEL MAR ARCE, ASCENSIÓN MARCOS \\ AND ANA MARÍA CASTRILLÓN \\ Instituto de Nutrición y Bromatología (CSIC), Facultad de Farmacia, Universidad Complutense, \\ Ciudad Universitaria, 28040 Madrid, Spain
}

(Received 29 January 1996 - Revised 24 September 1996 - Accepted 15 October 1996)

\begin{abstract}
Diets containing unheated casein (CD; control) or a casein-glucose mixture (CGD) previously heated at $140^{\circ}$ for $2 \mathrm{~h}$ were fed to two groups of young rats for $21 \mathrm{~d}$. Differences in body weight, feed consumption, thymus and spleen growth, protein metabolism and in vivo immune response were then determined. For this last experiment, animals were inoculated with sheep erythrocytes (SRBC) on day 15 to provide an immunological challenge. No changes were seen in body weight, feed consumption or feed conversion ratios. Neither were significant differences found in spleen weight, protein content, DNA content, DNase (EC 3.1.4.6) activity or lymphocyte count, suggesting that spleen cell growth remained similar in all the animals studied. The CGD induced marked increases in thymus DNA content whilst the protein:DNA ratio became lower. Spleen RNA content was similar in all rats, but thymus RNA content was $29 \%$ lower in the CGD group, although this difference did not reach statistical significance. This fact might be a consequence of the low RNase (EC 2.7.7.16) activity and RNase:RNA ratios in the thymus glands of CGD-fed animals. Further, the number of splenic plasma cells secreting anti-SRBC antibodies (direct plaque-forming cells) was significantly decreased in the same group. It might be concluded that both diets are adequate for rat growth and that the differences observed in the thymus of CGD-fed rats may be directed towards preserving tissue function. Nevertheless, the CGD did cause immunological disturbances affecting the humoral immune response.
\end{abstract}

Heat-processed diet: Maillard reaction: Immunocompetence: Thymus: Spleen

Processed foods are increasingly common in the human diet. Heat treatment is widely used to improve the taste and texture of food in commercial and home processing (grilling, baking, boiling, etc.). However, the heating of food proteins is known to have undesirable consequences. The Maillard browning reaction is one of the most important. This reaction occurs between reducing sugars and amino compounds (Adrian, 1974) and may alter the nutritional properties of food by reducing the availability of essential amino acids (mainly lysine). It may also reduce the digestibility of food and form potentially toxic compounds such as D-serine and D-tyrosine (Friedman et al. 1984). This should be taken into account when heat-processed food is consumed and further research is required to define the possible nutritional risks of its consumption (Finot, 1990).

In a study of the metabolism (absorption, excretion, etc.) of Maillard reaction products (MRP), Hurrell (1990) showed different physiological effects according to the Maillard reaction conditions. Matsuda et al. (1990) and Öste et al. (1990) studied the allergenic 
capacity of some proteins subjected to the Maillard reaction but their results were inconclusive.

The available literature concerning the effects of MRP on the nutritive value of foods is controversial and confused, and research is required to determine the effects of these compounds on tissues. Many cells of the immune system are known to rely on metabolic pathways whose mediators employ a range of nutrients as cofactors (Chandra, 1992). Some of these nutrients may act directly on the cells of the immune system, and alter their capacity to recognize foreign stimuli, leading to food allergies (Gershwin et al. 1985; Metcalfe, 1985).

Therefore, an investigation was made into protein metabolism in thymus and spleen cells of rats fed on diets containing either unheated casein or a heated protein + sugar mixture as the protein source. The in vivo immune response of the experimental animals was also studied. The latter is of particular interest in long-term feeding schedules since nutritionally-mediated immunological disturbances and infectious diseases may develop.

\section{MATERIALS AND METHODS}

\section{Animals and diets}

Three-week-old male Wistar rats (from the Instituto de Nutrición y Bromatología (CSIC), Madrid, Spain), weighing about $52 \mathrm{~g}$ were randomly assigned to two dietary groups of sixteen animals. As a source of protein the diets contained either raw casein (CD) or a mixture of casein + glucose (CGD) previously heated at $140^{\circ}$ for $2 \mathrm{~h}$ (Table 1). Animals were housed in individual polypropylene cages with wire-mesh bases and maintained at a temperature between 20 and $22^{\circ}$ and at $95 \%$ humidity. A $12 \mathrm{~h}$ day-night cycle was established. All animals had free access to feed and water. Individual body weights and feed intakes were recorded daily for $21 \mathrm{~d}$.

\section{Experimental designs and antigen and immunization patterns}

The experimental animals were allowed a $3 \mathrm{~d}$ period of adaptation to the diets. After following the diets for $21 \mathrm{~d}$ the immune responses of all animals were tested against an immunological challenge provided by sheep erythrocytes (SRBC; BioMérieux, Marcy l'Etoile, France). Before use, the cells were washed three times in $\mathrm{NaCl}$ solution $(8.5 \mathrm{~g} / \mathrm{l})$.

Table 1. Composition of experimental diets ( $\mathrm{g} / \mathrm{kg}$ diet)

\begin{tabular}{lcc}
\hline \hline & Casein diet (CD) & Casein-glucose diet (CGD) \\
\hline Casein (unheated) & 107.6 & - \\
Methionine & 2 & 2 \\
Casein + glucose (previousiy heated) & - & $153 \cdot 1$ \\
Sucrose & $375 \cdot 8$ & 353 \\
Wheat starch & 375.8 & 353 \\
Olive oil & 50 & 50 \\
Cellulose & 50 & 50 \\
Mineral mix* & 37.7 & 37.7 \\
Vitamin mix* & 1.2 & 1.2 \\
Energy content $(\mathrm{kJ} / \mathrm{kg})$ & 16120 & 16120 \\
Protein $(\mathrm{N} \times 6.25)$ & 100 & 100 \\
\hline
\end{tabular}

* Mineral and vitamin mixes were added to each diet according to the National Academy of Sciences (1978). 
Optimal production of anti-SRBC antibodies is seen after $5 \mathrm{~d}$ (Hudson \& Hay, 1989), therefore, animals were inoculated intraperitoneally on day 16 with $1.2 \times 10^{9} \mathrm{SRBC} / 0.5 \mathrm{ml}$ saline solution per $100 \mathrm{~g}$ body weight. At the end of the experimental period, animals were weighed and their spleens and thymus glands removed under diethyl ether anaesthesia.

\section{Manipulation of spleen and thymus and preparation of tissue extracts}

Eight spleens belonging to eight animals of each experimental group were used to assess spleen cell counts and the number of direct plaque-forming cells (DPFC). Using aseptic techniques, spleens were removed, weighed and placed in cold balanced salt solution (BSS) $\quad\left(\mathrm{NaCl} 136.9 \mathrm{mmol} / \mathrm{l}, \quad \mathrm{KCl} \quad 5.37 \mathrm{mmol} /, \mathrm{CaCl}_{2} 1.26 \mathrm{mmol} /, \mathrm{MgSO}_{4} .7 \mathrm{H}_{2} \mathrm{O}\right.$ $0.65 \mathrm{mmol} / \mathrm{l}, \mathrm{Na}_{2} \mathrm{HPO}_{4} 0.34 \mathrm{mmol} / \mathrm{l}, \mathrm{MgCl}_{2} .6 \mathrm{H}_{2} \mathrm{O} \quad 0.49 \mathrm{mmol} / \mathrm{l}, \mathrm{KH}_{2} \mathrm{PO}_{4} 0.44 \mathrm{mmol} / \mathrm{l}$, glucose $\left.5.55 \mathrm{mmol} / 1, \mathrm{NaHCO}_{3} 4.17 \mathrm{mmol} / 1 ; \mathrm{pH} 7.2-7.4\right)$. Cell suspensions were prepared by passing spleens through 100-mesh wire screens into BSS. Large clumps of cells were allowed to settle and the remaining suspension was gently agitated using a Pasteur pipette. Cells were counted using an automatic counter (Coulter Counter, Hialeah, FL, USA), and suspensions of $3 \times 10^{6}$ spleen lymphocytes were prepared for the DPFC assay. The spleens of the remaining eight rats of each experimental group were divided into two portions. One half was used to analyse spleen protein content and enzymic activities and the other to determine DNA and RNA contents.

The thymus glands of all sixteen rats were removed and divided into two portions. One portion of each gland was used to determine enzymic activity whilst the other was used to estimate DNA and RNA content.

The samples of spleen and thymus tissue, used to measure protein and enzymic activities respectively, were homogenized (Ultra-Turrax, Staupen i. Breisau, Germany) in cold buffer $\mathrm{pH} 7.4\left(0.15 \mathrm{M}-\mathrm{NaCl}, 5 \mathrm{mM}-\mathrm{NaHCO}_{3}\right)$ to produce a $200 \mathrm{~g} / \mathrm{l}$ tissue homogenate. Solids were removed by centrifugation at $500 \mathrm{~g}$ for $10 \mathrm{~min}$ and the supernatant fractions stored at $-20^{\circ}$ until use. In the remaining samples of spleen and thymus, DNA and RNA contents were determined after extraction with TCA.

\section{Determination of protein, DNA and RNA contents}

Spleen and thymus protein contents were determined by the Biuret reaction (Weichselbaum, 1946). RNA content was determined using the method of Munro \& Fleck (1966) and DNA content assessed according to the method of Burton (1956).

\section{Enzyme activity measurements}

Acid deoxyribonuclease (EC 3.1.4.6) and acid ribonuclease (EC 2.7.7.16) activities were assayed according to the methods of McDonald (1955) and Kalnitsky et al. (1959) with minor modifications (sample incubation periods were $45 \mathrm{~min}$ for DNase and $60 \mathrm{~min}$ for RNase).

\section{Evaluation of direct plaque-forming cells response}

At $5 \mathrm{~d}$ after inoculation with SRBC, the DPFC response was assayed in eight rats from each experimental group using the haemolytic plaque assay described by Cunningham \& Szenberg (1968). SRBC were used as target cells. The reaction mixture contained a $150 \mu \mathrm{l}$ spleen-cell suspension in a BSS medium, $40 \mu \mathrm{l}$ rabbit complement (Behring, Hoechst- 
Behring, France) and a $20 \mu 1$ SRBC suspension in phosphate buffered saline-glucose (PBS-glucose) ( $\mathrm{NaCl} 0.15 \mathrm{~mol} / \mathrm{l}, \mathrm{Na}_{2} \mathrm{HPO}_{4} 8.45 \mathrm{mmol} /$, $\mathrm{NaH}_{2} \mathrm{PO}_{4} 1.85 \mathrm{mmol} / \mathrm{l}$ ). Slides were incubated for $1 \mathrm{~h}$ at $37^{\circ}$ before plaques were counted.

\section{Statistical analysis}

Results are presented as arithmetic means with their standard errors. Differences between the group means were evaluated using the pooled $t$ test (Statistical Analysis Systems Institute Inc., 1989). Variables showing a high degree of variability e.g. DPFC (Table 7) were checked for the presence of outliers. Where the variabilities of the two treatment groups differed markedly the means were compared using an approximate $t$ test for unequal variances (separate $t$ test) (BMDP, 1992). Probability values of $P<0.05$ were considered to be significant.

\section{RESULTS}

\section{Growth performance and food intake measurements}

Initial and final body weight and weight gain were similar in both dietary groups. No differences were seen between the groups for feed and protein consumption. Feed conversion ratio remained unchanged in both dietary treatments (Table 2).

\section{Cellular growth in lymphoid tissues}

No differences were found between the two groups for spleen cell growth (Table 3). Spleen weight and protein and DNA contents as well as tissue lymphocyte count (see Table 7) were similar in both experimental groups. Neither were differences seen in acid DNase catalytic activity (Table 3 ). In the thymus (Table 4), CGD intake induced a marked increase in DNA content $(\mathrm{mg} / \mathrm{g}$ thymus $)(P=0.026)$ whilst the protein:DNA ratio diminished $(P=0.032)$. Nevertheless, no significant statistical differences were found between the groups for DNase activity or thymus lymphocyte count.

Table 2. Initial and final body-weights, daily feed intakes and feed conversion ratio of rats fed on diets containing unheated casein $(C D)$ or heated casein + glucose (CGD) as protein source* (Mean values with their standard errors for sixteen animals per dietary group)

\begin{tabular}{|c|c|c|c|c|c|}
\hline \multirow[t]{2}{*}{ Dietary treatment... } & \multicolumn{2}{|c|}{$\mathrm{CD}$} & \multicolumn{2}{|c|}{ CGD } & \multirow{2}{*}{$\begin{array}{c}\text { Statistical } \\
\text { significance of } \\
\text { difference } †\end{array}$} \\
\hline & Mean & SE & Mean & SE & \\
\hline Initial body weight (g) & $51 \cdot 25$ & 0.77 & 51.93 & 0.94 & NS \\
\hline Final body weight (g) & 133.45 & 9.19 & 145.00 & 5.26 & NS \\
\hline Weight gain (g/rat per d) & $4 \cdot 11$ & 0.46 & 4.66 & 0.27 & NS \\
\hline Daily feed intake $(g)$ & 10.96 & 0.73 & 12.19 & 0.43 & NS \\
\hline Daily protein intake (g) & 1.21 & 0.08 & 1.33 & 0.05 & NS \\
\hline Body-weight gain/protein intake $(\mathrm{g} / \mathrm{g})$ & $3 \cdot 37$ & 0.21 & 3.51 & 0.12 & NS \\
\hline Feed conversion ratio ( $\mathrm{g}$ intake/g gain) & 2.75 & 0.18 & 2.64 & 0.09 & NS \\
\hline
\end{tabular}

* For details of diets, see Table 1.

+ Degrees of freedom: CD 15, CGD 15. 
Table 3. Spleen cellular growth of rats given diets containing unheated casein (CD) or heated casein-glucose (CGD) as protein source*

(Mean values with their standard errors for eight animals per dietary group)

\begin{tabular}{|c|c|c|c|c|c|}
\hline \multirow[t]{2}{*}{ Dietary treatment... } & \multicolumn{2}{|c|}{$\mathrm{CD}$} & \multicolumn{2}{|c|}{ CGD } & \multirow{2}{*}{$\begin{array}{c}\text { Statistical } \\
\text { significance of } \\
\text { difference }{ }^{\dagger}\end{array}$} \\
\hline & Mean & SE & Mean & SE & \\
\hline Spleen index $\ddagger$ & 2.60 & 0.19 & 2.97 & 0.29 & NS \\
\hline Spleen weight (g) & 0.34 & 0.04 & 0.39 & 0.04 & NS \\
\hline Protein (mg/g spleen) & 89.84 & 1.56 & 86.54 & 2.45 & NS \\
\hline Protein (mg/spleen) & 31.08 & $3 \cdot 58$ & 34.30 & 2.98 & NS \\
\hline DNA (mg/spleen) & 5.32 & 0.75 & 5.87 & 0.95 & NS \\
\hline DNA (mg/g spleen) & $15 \cdot 40$ & 0.80 & 14.44 & 1.03 & NS \\
\hline Protein/DNA (mg/mg) & 5.93 & 0.36 & $6 \cdot 20$ & 0.64 & NS \\
\hline DNase (U/spleen) & 5.65 & 0.65 & $6 \cdot 12$ & 0.58 & NS \\
\hline DNase (U/mg protein) & 0.18 & 0.01 & 0.18 & 0.02 & NS \\
\hline DNase/DNA (U/mg) & $1 \cdot 10$ & 0.11 & $1 \cdot 19$ & 0.26 & NS \\
\hline
\end{tabular}

* For details of diets, see Table 1 .

+ Degrees of freedom: CD 7, CGD 7.

$\$$ Spleen weight $\left(\times 10^{3}\right) /$ final body weight.

Table 4. Thymus cellular growth of rats fed on diets containing unheated casein (CD) or heated casein-glucose (CGD) as protein source*

(Mean values with their standard errors for sixteen animals per dietary group)

\begin{tabular}{|c|c|c|c|c|c|}
\hline \multirow[t]{2}{*}{ Dietary treatment... } & \multicolumn{2}{|c|}{$\mathrm{CD}$} & \multicolumn{2}{|c|}{ CGD } & \multirow{2}{*}{$\begin{array}{l}\text { Statistical } \\
\text { significance o } \\
\text { difference } \uparrow\end{array}$} \\
\hline & Mean & SE & Mean & SE & \\
\hline Thymus index $\ddagger$ & 3.08 & $0 \cdot 38$ & 3.20 & 0.27 & NS \\
\hline Thymus weight (g) & 0.43 & 0.07 & 0.46 & 0.04 & NS \\
\hline Protein (mg/thymus) & 23.34 & 4.85 & 23.30 & 2.54 & NS \\
\hline Protein (mg/g thymus) & 54.03 & 4.02 & 50.23 & 2.46 & NS \\
\hline DNA (mg/thymus) & $8 \cdot 89$ & 1.61 & 11.97 & 1.62 & NS \\
\hline DNA (mg/g thymus) & $20 \cdot 81$ & 0.82 & 25.43 & 1.56 & $P=0.026$ \\
\hline Protein/DNA (mg/g) & 2.63 & 0.24 & 2.02 & 0.17 & $P=0.032$ \\
\hline DNase (U/thymus) & 5.83 & 1.23 & 5.40 & 0.89 & NS \\
\hline DNase (U/mg protein) & 0.22 & 0.01 & 0.24 & 0.20 & NS \\
\hline DNase/DNA (U/mg) & 0.64 & 0.07 & 0.47 & 0.05 & NS \\
\hline $\begin{array}{l}\text { Lymphocytes } \\
\text { (cells } \times 10^{6} / \text { thymus) }\end{array}$ & 569 & 64 & 587 & 81 & NS \\
\hline
\end{tabular}

* For details of diets, see Table 1.

$\uparrow$ Degrees of freedom: CD 15, CGD 15.

$\ddagger$ Thymus weight $\left(\times 10^{3}\right)$ /final body weight.

\section{RNA metabolism in lymphoid tissues}

RNA contents and RNA:protein ratio were similar in the spleen and thymus of rats in both dietary treatments (Tables 5 and 6). However, RNase activity (RNase/protein) $(P=0.034)$ and RNase/RNA $(P=0.019)$ were lower in thymus glands from animals of the CGD group (Table 6). 
Table 5. Spleen RNA metabolism of rats fed on diets containing unheated casein (CD) or heated casein-glucose (CGD) as protein source*

(Mean values with their standard errors for eight animals per dietary group)

\begin{tabular}{|c|c|c|c|c|c|}
\hline \multirow[t]{2}{*}{ Dietary treatment... } & \multicolumn{2}{|c|}{$\mathrm{CD}$} & \multicolumn{2}{|c|}{ CGD } & \multirow{2}{*}{$\begin{array}{l}\text { Statistical } \\
\text { significance of } \\
\text { difference } \dagger\end{array}$} \\
\hline & Mean & SE & Mean & SE & \\
\hline RNA (mg/spleen) & 3.73 & 0.44 & $4 \cdot 19$ & 0.47 & NS \\
\hline RNA (mg/g spleen) & 10.93 & 0.47 & $10 \cdot 51$ & 0.46 & NS \\
\hline RNA/protein (mg/mg) & 0.12 & 0.008 & 0.12 & 0.008 & NS \\
\hline RNase (U/spleen) & 0.25 & 0.03 & 0.27 & 0.03 & NS \\
\hline RNase (mU/mg protein) & 7.90 & 0.40 & $7 \cdot 85$ & 0.42 & NS \\
\hline RNase/RNA (mU/mg) & 65.90 & 5.60 & 64.6 & $2 \cdot 10$ & NS \\
\hline
\end{tabular}

* For details of diets, see Table 1.

† Degrees of freedom: CD 7, CGD 7.

Table 6. Thymus RNA metabolism of rats fed on diets containing unheated casein (CD) or heated casein-glucose (CGD) as protein source*

(Mean values with their standard errors for sixteen animals per dietary group)

\begin{tabular}{|c|c|c|c|c|c|}
\hline \multirow[t]{2}{*}{ Dietary treatment... } & \multicolumn{2}{|c|}{ CD } & \multicolumn{2}{|c|}{ CGD } & \multirow{2}{*}{$\begin{array}{l}\text { Statistical } \\
\text { significance of } \\
\text { difference } \dagger\end{array}$} \\
\hline & Mean & SE & Mean & SE & \\
\hline RNA (mg/thymus) & 3.49 & 0.5 & 4.90 & 0.67 & NS \\
\hline RNA (mg/g thymus) & $8 \cdot 12$ & 0.51 & 10.44 & 0.70 & NS \\
\hline RNA/protein (mg/mg) & 0.17 & 0.02 & 0.21 & 0.01 & NS \\
\hline RNase (U/thymus) & 0.11 & 0.02 & 0.08 & 0.01 & NS \\
\hline RNase (mU/mg protein) & 4.83 & 0.42 & 3.57 & 0.13 & $P=0.034$ \\
\hline RNase/RNA (U/mg) & $3 \cdot 14$ & 0.004 & 1.71 & 0.001 & $P=0.019$ \\
\hline
\end{tabular}

* For details of diets, see Table 1.

$\uparrow$ Degrees of freedom: CD 15, CGD 15.

\section{Assessment of immunological response}

The spleen lymphocyte count was similar in both experimental groups (Table 7). The number of splenic plasma cells secreting anti-SRBC antibodies (DPFC) was significantly reduced in CGD-fed rats, both in absolute terms $(P=0.01)$ and when expressed per $10^{6}$ spleen cells $(P=0.004)$.

\section{DISCUSSION}

The dietary intake and body-weight values (Table 2) recorded in this study provide evidence that a casein + glucose diet can be considered nutritionally adequate for rat growth. All animals showed a positive weight gain during the experimental period. These results agree with those reported by Kimiagar et al. (1980) in a study of rats fed on a diet containing $100 \mathrm{~g} \mathrm{MRP} / \mathrm{kg}$ for 1 month. Though damage to the lysine component of the heat-treated diet could be expected (this amino acid is the most affected by heat treatment in the presence of reducing sugars (Hurrell et al. 1983)) no adverse effects were seen with respect to the variables mentioned earlier. According to Said et al (1974), adaptation to 
Table 7. Direct plaque-forming cells (DPFC) response in spleen of rats fed on diets containing unheated casein $(C D)$ or heated casein-glucose (CGD) as protein source*

(Mean values with their standard errors for eight animals per dietary group)

\begin{tabular}{|c|c|c|c|c|c|}
\hline \multirow[t]{2}{*}{ Dietary treatment... } & \multicolumn{2}{|c|}{$\mathrm{CD}$} & \multicolumn{2}{|c|}{ CGD } & \multirow{2}{*}{$\begin{array}{l}\text { Statistical } \\
\text { significance o } \\
\text { difference }\end{array}$} \\
\hline & Mean & SE & Mean & SE & \\
\hline $\begin{array}{l}\text { Lymphocytes } \ddagger \text { (cells } \times 10^{6} / \text { spleen) } \\
\text { Spleen DPFC }\left(\times 10^{-3}\right) \S \\
\text { DPFC }\left(/ 10^{6} \text { cells }\right) \S\end{array}$ & $\begin{array}{r}347 \\
582 \\
1647\end{array}$ & $\begin{array}{r}11 \\
97 \\
238\end{array}$ & $\begin{array}{l}384 \\
254 \\
664\end{array}$ & $\begin{array}{l}24 \\
18 \\
32\end{array}$ & $\begin{array}{c}\text { NS } \\
P=0.01 \\
P=0.004\end{array}$ \\
\hline
\end{tabular}

* For details of diets, see Table 1.

+ Degrees of freedom: CD 7, CGD 7.

$\ddagger$ Pooled $t$ test.

$\$$ Separate $t$ test.

lysine-free diets is clear and marked. Rats given no lysine still show apparently adequate intakes and lose weight and tissue much more slowly than animals fed on diets deficient in threonine, isoleucine or total $\mathbf{S}$ amino acids. This may explain the normal rat growth observed in the present study.

No significant differences were found between the groups with respect to spleen weight, spleen-somatic index, spleen DNA levels, or spleen DNA catabolism (Table 3) or RNA metabolism (Table 5). In the same way, Kimiagar et al. (1980) observed no spleen weight loss in rats fed on MRP for 1 month. Similar results were reported by Martínez et al. (1992) in spleens from mice which had been fed on either casein or Vicia faba as a protein source. However, Srivastava et al. (1975), Muñoz et al. (1981) and Martinez et al. (1992) found that spleen protein and DNA contents decreased in rats fed on altered quality and/or quantity of protein. Under malnutrition conditions, Kenney et al (1968) and Srivastava et al. (1975) reported that rat spleen RNA levels were reduced. In such conditions spleen RNA catabolism remains unmodified in order to maintain RNA content as much as possible (Muñoz et al. 1981).

Thymus cell atrophy (Table 4) was observed in CGD-fed animals, caused mainly by higher (26\%) DNA content in the thymus. A high variability was found for these data, and as a consequence, the difference between the means was not detected as significant. When DNA content was expressed per weight unit $(\mathrm{g})$ of thymus, a statistically significant difference was found. Low DNA levels in lymphoid organs (Srivastava et al. 1975) and thymus lymphocyte counts have been reported under malnutrition conditions (Bell et al. 1976). With respect to thymus DNA catabolism, DNase/mg DNA was $36 \%$ lower in the CGD group than in the CD group, although no statistically signficant difference was detected. Muñoz et al. (1981) observed no modifications in acid DNase activity of the thymus glands of growing rats fed on a low-protein diet for $20 \mathrm{~d}$. However, after $30 \mathrm{~d}$ these authors reported increased DNase levels, leading to organ involution.

Thymus RNA levels were statistically similar in the two groups, in spite of the fact that the absolute and relative thymus RNA contents were 29 and $22 \%$ higher respectively in the CGD group than in the CD group. This may be due to lowered RNase catabolic activity (Table 6). These results are similar to those of Muñoz et al. (1981) who reported lower thymus RNA catabolism in growing rats fed on a protein-deficient diet for 3 weeks. Since non-significant differences were seen between the two groups in either protein or RNA levels, no significant difference was found in protein synthesis capacity (RNA:protein 
ratio), although the mean of the CGD group was $19 \%$ higher than that of the CD group, possibly as a consequence of the data variability observed in the CD group.

The humoral immune response to SRBC was measured in the DPFC assay, a technique which provides information on the immunoglobulin $\mathbf{M}(\mathrm{IgM})$ response (Hudson \& Hay, 1989). The results of this investigation show that the DPFC count was markedly reduced in the CGD-fed rats (Table 7) in spite of the spleen lymphocyte count remaining unmodified. Moreover, it seems relevant to point out that the CD group's DPFC responses showed great variation while in the CGD group this was smaller. It might indicate that the heated diet modulates the immune response more tightly. Impairment of immunity has been found by other authors (Stolzner \& Dorsey, 1980; Petro \& Bhattacharjee, 1981; Woodward \& Miller, 1991; Woodward et al. 1992) in mice maintained in protein and amino aciddeficient conditions. According to Bounous \& Kongshavn (1985), the effects of altered dietary protein type on the humoral immune response are not exerted only on the rate of primary B-lymphocyte production in the bone marrow, but also alter the functional responsiveness of the $B$ lymphocytes themselves, during their activation and differentiation in the peripheral lymphoid tissues. Dysfunction of antigen-presenting cells may also occur (Boswell et al. 1980; Conzen \& Janeway, 1988). This would modify the complex sequence of events in B lymphocyte activation, clonal expansion and antibody secretion. Moreover, it has been pointed out that glycosylated proteins, formed after long-term exposure to glucose, are recognized and endocytosed by rat sinusoidal liver cells and peritoneal macrophages (Vlassara et al. 1985; Takata et al. 1988). In view of these findings, it might be suggested that the macrophages of rats fed on the heated protein-glucose mixture would respond to dietary glycosylated proteins. A possible deficiency in amino acids and a possible response by macrophages could contribute to the depressed humoral immune function observed in the present study.

It may be concluded that both diets are adequate for rat growth. The modifications observed in the thymus glands of animals fed on CGD may be directed towards preserving tissue function. Nevertheless, the heat-treated CGD did cause immunological disturbances affecting the humoral immune response, something that has not been evaluated previously when using rats as an experimental model and heated protein + reducing sugar as the dietary source of protein. There is, therefore, a possibility that nutritionally-mediated immunological disturbances, both in animals and man, could occur in long-term consumption of heat-processed foods.

Financial support from the Comisión Interministerial de Ciencia y Tecnología (ALI880255) is gratefully acknowledged. M.M.A. was sponsored by a predoctoral grant from Universidad Complutense de Madrid.

\section{REFERENCES}

Adrian, J. (1974). Nutritional and physiological consequences of the Maillard reaction. In World Reviews of Nutrition and Dietetics, vol. 19, pp. 71-122 [G. H. Bourne, editor]. Basel: S. Karger.

Bell, R. G., Hazell, L. A. \& Price, P. (1976). Influence of dietary protein restriction on immune competence. II. Effect of lymphoid tissue. Clinical and Experimental Immunology 26, 314-319.

BMDP (1992). BMDP Statistical Software, release 7. Los Angeles: California University.

Boswell, H. S., Nerenberg, M. I., Scher, I. \& Singer, A. (1980). Role of accessory cells in B cell activation. Journal of Experimental Medicine 152, 1194-1209.

Bounous, G. \& Kongshavn, P. A. L. (1985). Differential effect of dietary protein type on the B-cell and T-cell immune responses in mice. Journal of Nutrition 115, 1403-1408.

Burton, K. (1956). A study of the conditions and mechanism of the diphenylamine reaction for the colorimetric estimation of deoxyribonucleic acid. Biochemical Journal 62, 315-323. 
Chandra, R. K. (1992). The first INIG Award Lecture. Nutrition and immunology: experience of an old traveller and recent observations. In Nutrition and Immunology, pp. 9-43 [R. K. Chandra, editor]. St. John's, Newfoundland: ARTS Biomedical Publishers and Distributors.

Conzen, S. D. \& Janeway, C. A. (1988). Defective antigen presentation in chronically protein-deprived mice. Immunology 63, 683-689.

Cunningham, A. J. \& Szenberg, A. (1968). Further improvements in the plaque technique for detecting single antibody forming cells. Immunology 14, 599-601.

Finot, P. A. (1990). Metabolism and physiological effects of Maillard reaction products (MRP). In The Maillard Reaction in Food Processing, Human Nutrition and Physiology, pp. 259-272 [P. A. Finot, H. U. Aeschbacher, R. F. Hurrell and R. Liardon, editors]. Basel: Birkhäuser Verlag.

Friedman, M., Gumbmann, M. R. \& Masters, P. M. (1984). Protein-alkali reaction: chemistry, toxicology, and nutritional consequences. In Nutritional and Toxicological Aspects of Food Safety, pp. 367-411 [M. Friedman, editor]. New York: Plenum Press.

Gershwin, M. E., Beach, R. S. \& Hurley, L. S. (1985). Nutrition and Immunity. London: Academic Press.

Hudson, L. \& Hay, F. C. (1989). Practical Immunology. Oxford: Blackwell Scientific Publications.

Hurrell, R. F. (1990). Influence of the Maillard reaction on the nutritional value of foods. In The Maillard Reaction in Food Processing, Human Nutrition and Physiology, pp. 245-258 [P. A. Finot, H. U. Aeschbacher, R. F. Hurrell and R. Liardon, editors]. Basel: Birkhäuser Verlag.

Hurrell, R. F., Finot, P. A. \& Ford, J. E. (1983). Storage of milk powders under adverse conditions. 1. Losses of lysine and other essential amino acids. British Journal of Nutrition 49, 343-354.

Kalnitsky, G., Hummel, J. P., Resnick, H., Carter, J. R., Barnett, L. B. \& Dierks, C. (1959). The relation of structure to enzymatic activity in ribonuclease. Annals of the New York Academy of Sciences 81, 542-566.

Kenney, M. A., Roderuck, C. E., Arnrich, L. \& Piedad, F. (1968). Effect of protein deficiency on the spleen and antibody formation in rats. Joumal of Biological Chemistry 92, 623-629.

Kimiagar, M., Lee, T. C. \& Chichester, C. O. (1980). Long-term feeding effects of browned egg albumin to rats. Journal of Agricultural and Food Chemistry 28, 150-155.

McDonald, M. R. (1955). Methods in Enzymology, vol. 2. New York: Academic Press.

Martinez, J. A., Macarulla, M. T., Marcos, R. \& Larralde, J. (1992). Nutritional outcome and immunocompetence in mice fed on a diet containing raw field beans (Vicia faba, var. minor) as the source of protein. British Journal of Nutrition 68, 493-503.

Matsuda, T., Ishiguro, H., Okubo, I., Sasaki, M. \& Nakamura, R. (1990). Immunodominancy and antigenic structure of lactose-protein Maillard adduct. In The Maillard Reaction in Food Processing, Human Nutrition and Physiology, pp. 297-302 [P. A. Finot, H. U. Aeschbacher, R. F. Hurrell and R. Liardon, editors]. Basel: Birkhäuser Verlag.

Metcalfe, D. D. (1985). Food allergens. Clinical Reviews of Allergy 3, 331-349.

Muñoz, E., Marcos, A. \& Unzaga, M. T. (1981). Effect of protein on the lysosomal enzyme activities of the spleen and thymus of weanling rats. Journal of Nutrition 111, 2133-2141.

Munro, H. N. \& Fleck, A. (1966). Recent developments in the measurement of nucleic acids in biological material. Analyst 91, 78-88.

National Academy of Sciences (1978). Nutrient Requirements of Laboratory Animals, 3rd ed. Washington, DC: National Academy of Sciences.

Öste, R. E., Brandon, D. L., Bates, A. \& Friedman, M. (1990). Antibody-binding to a Maillard-reacted protein. In The Maillard Reaction in Food Processing, Human Nutrition and Physiology, pp. 303-308 [P. A. Finot, H. U. Aeschbacher, R. F. Hurrell and R. Liardon, editors]. Basel: Birkhäuser Verlag.

Petro, T. M. \& Bhattacharjee, J. K. (1981). Effect of dietary essential amino acid limitations upon the susceptibility to Salmonella typhimurium and the effect upon humoral and cellular immune responses in mice. Infection and Immunity 32, 251-257.

Said, A. K., Hegsted, D. M. \& Hayes, K. C. (1974). Response of adult rats to deficiencies of different essential amino acids. British Journal of Nutrition 31, 47-57.

Srivastava, U., Spach, C. \& Aschkenasy, A. (1975). Cyclic AMP metabolism and nucleic acid content in the lymphocytes of the thymus, spleen and lymph nodes of protein-deficient rats. Journal of Nutrition 105, 924 928.

Statistical Analysis Systems Institute Inc. (1989). SAS/STAT User's Guide, version 6, 4th ed., vol. 1, 2. Cary, NC: SAS Institute Inc.

Stoltzner, G. H. \& Dorsey, B. A. (1980). Life-long dietary protein restriction and immune function: responses to mitogens and sheep erythrocytes in BALB/c mice. American Journal of Clinical Nutrition 33, $1264-1271$.

Takata, K., Horiuchi, S., Araki, N., Shiga, M., Saitoh, M. \& Morino, Y. (1988). Endocytic uptake of nonenzymatically glycosylated proteins is mediated by a scavenger receptor for aldehyde-modified proteins. Journal of Biological Chemistry 263, 14819-14825.

Vlassara, H., Brownlee, M. \& Cerami, A. (1985). High-affinity-receptor-mediated uptake and degradation of glucose-modified proteins: a potential mechanism for the removal of senescent macromolecules. Proceedings of the National Academy of Sciences, USA 82, 5588-5592. 
Weichselbaum, T. E. (1946). An accurate and rapid method for the determination of proteins in small amounts of blood serum and plasma. American Journal of Clinical Pathology 16, 40-49.

Woodward, B. D. \& Miller, R. G. (1991). Depression of thymus-dependent immunity in wasting protein-energy malnutrition does not depend on an altered ratio of helper (CD4 + ) to suppressor (CD8 + ) $\mathrm{T}$ cells or a disproportionately large atrophy of T-cell relative to the B-cell pool. American Journal of Clinical Nutrition 53, 1329-1335.

Woodward, B. D., Woods, J. W. \& Crouch, D. A. (1992). Direct evidence that primary acquired cell-mediated immunity is less resistant than is primary thymus-dependent humoral immunity to the depressive influence of wasting protein-energy malnutrition in weanling mice. American Journal of Clinical Nutrition 55, 11801185. 